\title{
GCU
}

Glasgow Caledonian

University

University for the Common Good

\section{Measuring experience and outcomes in patients reporting sexual violence who attend a healthcare setting: a systematic review}

Caswell, Rachel J.; Ross, Jonathan D.C.; Lorimer, Karen

Published in:

Sexually Transmitted Infections

DOI:

10.1136/sextrans-2018-053920

Publication date:

2019

Document Version

Author accepted manuscript

Link to publication in ResearchOnline

Citation for published version (Harvard):

Caswell, RJ, Ross, JDC \& Lorimer, K 2019, 'Measuring experience and outcomes in patients reporting sexual violence who attend a healthcare setting: a systematic review', Sexually Transmitted Infections, vol. 95, no. 6, pp. 419-427. https://doi.org/10.1136/sextrans-2018-053920

\section{General rights}

Copyright and moral rights for the publications made accessible in the public portal are retained by the authors and/or other copyright owners and it is a condition of accessing publications that users recognise and abide by the legal requirements associated with these rights.

Take down policy

If you believe that this document breaches copyright please view our takedown policy at https://edshare.gcu.ac.uk/id/eprint/5179 for details of how to contact us. 
Measuring experience and outcomes in patients reporting sexual violence who attend a health care setting: a systematic review

Rachel Caswell", University Hospitals Birmingham NHS Foundation Trust, Sexual Health and HIV Medicine Department, Mindelsohn Way, Birmingham, B15 2TH, UK. Phone: (44) 1212375721 Fax: (44) 1212375729 Email: rachelcaswell@nhs.net

Jonathan D.C. Ross, Sexual Health and HIV Medicine Department, University Hospitals Birmingham NHS Trust, Birmingham, UK

Karen Lorimer, School of Health \& Life Sciences, Glasgow Caledonian University, Scotland, UK

*Corresponding author

Keywords

Systematic Reviews

Patient Reported Outcome Measures

Patient satisfaction

Violence

Sexual Health

Qualitative Research 


\begin{abstract}
Background:

Obtaining perspectives from those seeking healthcare after sexual violence on care and how it's delivered is important.
\end{abstract}

Objectives: To systematically identify any existing patient reported outcome and experience measures (PROMs and PREMs) for patients attending healthcare services after sexual violence. Also, to identify key themes regarded by patients as priorities for delivering a high-quality service.

Design: Systematic review (PROSPERO registration RD42016050297)

Data sources: Eight electronic bibliographic databases from inception to March 2017. 'Grey' literature also searched. Search words included patient view, patient experience, PROM/PREM, sexual violence, rape.

Review methods: Studies of any design, with participants of any gender and aged 13 years or older were included; studies only assessing the views of service providers were excluded. Appraisal tools assessed for study quality. Healthcare outcome data were assessed across the quantitative studies and key experiences across qualitative papers; Framework Analysis was used to synthesise the qualitative studies.

Results: From 4153 identified papers 20 fulfilled criteria for inclusion: 10 qualitative, eight quantitative and two mixed methods. No validated measure of assessing patient experience or outcome was identified. The synthesis of qualitative studies led to the assignment of two overarching themes around the importance of patient- and trauma focused communication, and of care which enhances patient empowerment. A paucity of research within certain patient groups who experience sexual violence, in particular men and LGBT (lesbian, gay, bisexual and trans) patients was noted.

Limitations: A broad definition of 'healthcare setting' incorporated a wide variety of venues limiting the applicability of findings in specific settings.

Conclusion: A validated and standardised approach to assess patient experience and outcome in healthcare settings after sexual violence is needed. Themes identified should be incorporated into PROM or PREM development. The review also suggests the need for a change in approach towards those who attend for healthcare after sexual violence to ensure patient autonomy. 


\section{BACKGROUND}

Sexual violence can result in significant medical, psychosocial, economic and legal needs, necessitating a complex response from health, criminal justice, social, education and police systems. [1] Whilst attendance at a healthcare setting may be only one aspect of a person's overall support, it is well recognised as being central to their recovery and well-being. [1,2] Disclosure of sexual violence to health care professionals is challenging and has been known to result in patient experiences that run counter to the person-centered care championed by the NHS and NICE.[3-7] Recognising that people seeking health care after sexual violence have greater barriers in accessing care than other groups, highlights the importance of obtaining their perspective on how care is delivered. [8]

Patient-reported indicators measure health status or the experience of receiving health care from the patients' perspective. Measures of patient-reported experience (PREMs) assess the patient's view towards their experience of the healthcare they received, whilst patient-reported outcomes (PROMs) give insight into patients' self-reported health status.[9] Whilst a validated patient satisfaction survey tool has been developed for sexual health clinic attendees,[10] those who attend healthcare after sexual violence have distinct needs and are likely to require a different or additional set of measures.

No systematic review of the measurement of patient experience and outcome in health care settings on receiving care after sexual violence has previously been performed. We conducted a systematic review to: determine how PROMs and PREMs have previously been defined and measured for people attending health care settings after experiencing sexual violence; identify whether a "gold standard" measure of PROMs and PREMs exists for this group of patients, and if so how has it been defined in terms of reliability (are the results reproducible and consistent), validity (has an assessment been made of what patients consider to be important measures of quality and are they accurately evaluated), acceptability and feasibility. We also sought to use the review findings to identify key themes regarded by patients as priorities for delivering a high-quality service for individuals who have experienced sexual violence.

\section{METHODS}

The protocol for this systematic review was registered on PROSPERO, RD42016050297 http://www.crd.york.ac.uk/PROSPERO/display_record.php?ID=CRD42016050297[11]

\section{Search methods for identification of studies}

Searches were conducted in Medline, Embase, CINHAL (Index to Nursing and Allied Health), Cochrane database, PsycINFO (American psychological database), AMED (Allied and Complementary medicine 
database), BNI (British Nursing Index), ASSIA (Applied Social Sciences Index and Abstracts) using keywords and $\mathrm{MeSH}$ terms relating to patient reported experience and outcomes and sexual violence from inception until May 2017 (online supplementary material 1). Methodological filters to identify specific study designs reduced the sensitivity of the searches and were, therefore, not applied. A 'grey' literature search using Web of Science, the British Library and Open Grey was performed. Additionally, we searched reference lists of identified articles and conducted citation searches of key studies. Authors were contacted for clarification if needed.

\section{Study eligibility criteria}

Studies were considered eligible if they included either patient reported experience or outcomes. Specific study eligibility criteria were: (1) participants of any gender, aged 13 years or older (2) history of sexual violence as either defined by the UK Sexual Offences Act 2003 or serious sexual violence was reported to have occurred (3) presentation to healthcare settings including, but were not limited to: primary care (e.g. GP, school nurse/health visitor); sexual health clinics; Emergency department and hospitals; SARC (Sexual Assault Referral Clinics); third sector organizations whose primary remit during the attendance of the client includes health care of those having experienced sexual violence. Studies only assessing the views of service providers were not eligible for inclusion. All study designs were considered.

\section{Selection of studies and data extraction}

One reviewer scanned the abstracts and titles, after ensuring concurrence with a second reviewer for the first 100 articles, using the criteria described above. Two authors independently assessed full text articles that appeared to meet eligibility criteria; disagreements were resolved by consensus, with a third author available to resolve the issue when needed. Two data extraction proformas, for quantitative and qualitative data, were drafted, reviewed, piloted and refined by the authors.

\section{Quality assessment}

Using a modified version of the JBI appraisal tool,[12] a checklist for analytical cross-sectional studies, each quantitative study was assessed for its methodological quality and the extent to which the authors had addressed the possibility of bias in its design, conduct and analysis. For PROMs or PREMs the COSMIN tool was used to assess quality.[13] Qualitative studies were assessed for quality using the JBI appraisal tool for qualitative studies.[14]

\section{Synthesis}

We planned to determine how PROMs and PREMs had been previously defined and see if a "gold standard" measure of PROMs and PREMs exists for this group of patients. However, this was not possible since no PROMs or PREMs were identified. Data were extracted to identify healthcare outcomes that had been assessed across the quantitative studies, and key experiences detailed across qualitative papers; Framework Analysis was used to synthesise the qualitative studies, and relevant components of 
mixed methods studies.[15] NVivo software for Mac (Version 10) was used to manage the qualitative synthesis.

\section{RESULTS}

7563 abstracts and titles were identified and reduced to 4153 after removing duplicates. After reviewing titles and abstracts, 184 papers were then assessed as full texts, resulting in the inclusion of 21 references. One study generated two papers, [16, 17] thus 20 studies were included. Of these 20 studies, 10 used qualitative research methods, eight used quantitative and two mixed methods. Included studies are summarised in Tables 1a and 1b.

No specific PROMs and PREMs in relation to attendance at a healthcare setting after sexual violence were identified. Although validated measures e.g., Beck Depression tool, were employed in some studies to measure outcomes these assessed the effects of therapy rather than obtaining patient opinions on the support required. The quantitative studies were used to identify the type of care provided, and the nature of the interaction with healthcare professionals. The qualitative studies identified key themes regarded as priorities. 
Table 1a: Included studies by study design: Quantitative

\begin{tabular}{|c|c|c|c|c|c|}
\hline Study & Study design & Country & Aim of study & $\begin{array}{l}\text { Study population: } \\
\text { Participant numbers; Sex; } \\
\text { Ethnicity; } \\
\text { Sexual orientation (SO). }\end{array}$ & $\begin{array}{l}\text { Setting, } \\
\text { intervention }\end{array}$ \\
\hline \multicolumn{6}{|l|}{ QUANTITATIVE STUDIES } \\
\hline $\begin{array}{l}\text { Campbell et al. } 2005 \\
\text { [16] (Campbell et al. } \\
\text { 2006) [17] }\end{array}$ & $\begin{array}{l}\text { Quantitative; } \\
\text { survey (face to } \\
\text { face) }\end{array}$ & USA & $\begin{array}{l}\text { To quantify patient outcomes after rape } \\
\text { examination and patient experiences of the } \\
\text { behaviours of healthcare professionals } \\
\text { including secondary victimization. }\end{array}$ & $\begin{array}{l}\mathrm{N}=81 ; \\
\text { Female; } \\
\text { African American 52\%, White 37\%, } \\
\text { Latina } 8 \% \text {, multiracial 3\%; } \\
\text { SO not stated }\end{array}$ & $\begin{array}{l}\text { Acute medical } \\
\text { /Forensic }\end{array}$ \\
\hline $\begin{array}{l}\text { Campbell et al. } 2008 \\
\text { [18] }\end{array}$ & $\begin{array}{l}\text { Quantitative; } \\
\text { survey (written) }\end{array}$ & USA & $\begin{array}{l}\text { Which tool (person/phone/paper) was } \\
\text { preferable for collecting data from patients } \\
\text { after rape? Secondary aim provided results } \\
\text { of this data. }\end{array}$ & $\begin{array}{l}\mathrm{N}=52 \\
\text { Not stated; } \\
68 \% \text { white; } \\
\text { SO not stated }\end{array}$ & $\begin{array}{l}\text { Acute } \\
\text { medical/Forensic }\end{array}$ \\
\hline Denis et al. 2015 [19] & $\begin{array}{l}\text { Quantitative; } \\
\text { survey (written) }\end{array}$ & France & $\begin{array}{l}\text { To assess patient's perspectives on care } \\
\text { they receive after rape in an acute setting. }\end{array}$ & $\begin{array}{l}\mathrm{N}=232 ; \\
\text { Female } \mathrm{n}=221 \text {, male } \mathrm{n}=11 ; \\
\text { Ethnicity not stated; } \\
\text { SO not stated }\end{array}$ & $\begin{array}{l}\text { Acute medical } \\
\text { (pre-forensic) }\end{array}$ \\
\hline Hall et al. 1997 [20] & $\begin{array}{l}\text { Quantitative; } \\
\text { survey (written) }\end{array}$ & UK & $\begin{array}{l}\text { To assess how beneficial patients (and } \\
\text { healthcare professionals) felt group therapy } \\
\text { was for adults who have experienced child } \\
\text { sexual abuse. }\end{array}$ & $\begin{array}{l}\mathrm{N}=54 ; \\
\text { Female; } \\
\text { Ethnicity not stated; } \\
\text { SO not stated }\end{array}$ & $\begin{array}{l}\text { Mental health } \\
\text { (specialised) }\end{array}$ \\
\hline $\begin{array}{l}\text { Monroe et al. } 2005 \\
\text { [21] }\end{array}$ & $\begin{array}{l}\text { Quantitative; } \\
\text { survey (face to } \\
\text { face) }\end{array}$ & USA & $\begin{array}{l}\text { Broad aims that included assessment, } \\
\text { experiences, needs and recommendations } \\
\text { after sexual assault }\end{array}$ & $\begin{array}{l}\mathrm{N}=125 ; \\
\text { Female } \mathrm{n}=119 \text {, male } \mathrm{n}=6 ; \\
\text { White } 76 \% \text {, African American } \\
12.8 \% \text {, Hispanic } 2.4 \% \text {, American } \\
\text { Indian } 1.6 \% \text {, other } 7.2 \% \text {; } \\
\text { SO not stated }\end{array}$ & $\begin{array}{l}\text { Rape crisis } \\
\text { centres }\end{array}$ \\
\hline Smith el al. 1995 [22] & $\begin{array}{l}\text { Quantitative; } \\
\text { survey (written) }\end{array}$ & UK & $\begin{array}{l}\text { Evaluation of a pilot therapy service for } \\
\text { adults who have been abused as children }\end{array}$ & $\begin{array}{l}\mathrm{N}=92 ; \\
\text { Female } \mathrm{n}=56, \text { male } \mathrm{n}=11 \text { (sample); } \\
\text { Ethnicity not stated; } \\
\text { SO not stated }\end{array}$ & $\begin{array}{l}\text { Mental health } \\
\text { (specialised) }\end{array}$ \\
\hline
\end{tabular}




\begin{tabular}{|l|l|l|l|l|}
\hline $\begin{array}{l}\text { Wasco et al. 2004 } \\
\text { [23] }\end{array}$ & $\begin{array}{l}\text { Quantitative; } \\
\text { survey (face to } \\
\text { face and written) }\end{array}$ & USA & $\begin{array}{l}\text { To evaluate the impact of services on rape } \\
\text { survivors }\end{array}$ & $\begin{array}{l}\text { N=218 } \\
\text { Female; } \\
\text { African American 7.4\%, Caucasian } \\
74.5 \%, \text { Hispanic or Latina 10\%, } \\
\text { other 3.9\% (counselling recipients); } \\
\text { SO not stated }\end{array}$ \\
\hline Zweig et al. 2007 [24] & $\begin{array}{l}\text { Quantitative } \\
\text { survey (phone) }\end{array}$ & USA & $\begin{array}{l}\text { Did the way services were set up or } \\
\text { interacted enable the researchers to predict } \\
\text { how helpful women would find them? }\end{array}$ & $\begin{array}{l}\text { N=100; } \\
\text { Female; } \\
\text { Ethnicity not stated; } \\
\text { SO not stated }\end{array}$ \\
\hline
\end{tabular}


Table 1b: Included studies by study design: Mixed method and Qualitative

\begin{tabular}{|c|c|c|c|c|c|}
\hline Study & Study design & Country & Aim of study & $\begin{array}{l}\text { Study population: } \\
\text { Participant numbers; Sex; Ethnicity; } \\
\text { Sexual orientation (SO). }\end{array}$ & $\begin{array}{l}\text { Setting, } \\
\text { intervention }\end{array}$ \\
\hline \multicolumn{6}{|c|}{ MIXED METHOD STUDIES } \\
\hline $\begin{array}{l}\text { Lewis-O'Connor et } \\
\text { al. } 2015 \text { [25] }\end{array}$ & $\begin{array}{l}\text { Mixed methods } \\
\text { (phone NB text } \\
\text { message to } \\
\text { engage initially) }\end{array}$ & USA & $\begin{array}{l}\text { Quantitative element - to understand patient } \\
\text { perspectives on forensic collection and } \\
\text { whether they regretted having it done or not. }\end{array}$ & $\begin{array}{l}\mathrm{N}=190 \text { (sexual assault group); } \\
\text { Female; } \\
\text { Ethnicity not stated; } \\
\text { SO not stated }\end{array}$ & $\begin{array}{l}\text { Acute } \\
\text { medical/forensic }\end{array}$ \\
\hline $\begin{array}{l}\text { Starzynski et al. } \\
2011[26]\end{array}$ & $\begin{array}{l}\text { Mixed methods } \\
\text { (written survey) } \\
\text { (semi- } \\
\text { structured } \\
\text { interviews) }\end{array}$ & USA & $\begin{array}{l}\text { Women's experiences of disclosing sexual } \\
\text { assault }\end{array}$ & $\begin{array}{l}\mathrm{N}=365 ; \\
\text { Female; } \\
\text { White } 47.2 \% \text {, African American } 36.4 \% \text {, } \\
\text { multiracial } 8.1 \% \text {, Latina 5.3\%, Asian 1.9\%, } \\
<1 \text { Pacific islander/native Hawaiian; } \\
\text { Heterosexual } 69.5 \% \text {, homosexual, bisexual } \\
\text { or unsure } 31.5 \%\end{array}$ & Mental health \\
\hline \multicolumn{6}{|c|}{ QUALITATIVE STUDIES } \\
\hline $\begin{array}{l}\text { Barros et al. } 2015 \\
{[3]}\end{array}$ & $\begin{array}{l}\text { Qualitative, } \\
\text { individual } \\
\text { interviews }\end{array}$ & Brasil & $\begin{array}{l}\text { How was the experience of rape victims } \\
\text { (women) who sought assistance in reference } \\
\text { healthcare services? }\end{array}$ & $\begin{array}{l}\mathrm{N}=11 ; \\
\text { Female; } \\
\text { Ethnicity not stated; } \\
\text { SO not stated }\end{array}$ & $\begin{array}{l}\text { Outpatient clinic of } \\
\text { a maternity } \\
\text { hospital }\end{array}$ \\
\hline $\begin{array}{l}\text { Campbell et al. } \\
2013[4]\end{array}$ & $\begin{array}{l}\text { Qualitative, } \\
\text { semi-structured } \\
\text { individual } \\
\text { interviews }\end{array}$ & USA & $\begin{array}{l}\text { To examine how adolescent sexual assault } \\
\text { patients characterized the quality of the } \\
\text { emotional/interpersonal care they received } \\
\text { and to identify specific aspects of nursing } \\
\text { practice that were helpful and healing }\end{array}$ & $\begin{array}{l}\mathrm{N}=20 ; \\
\text { Female; } \\
\text { White ( } \mathrm{n}=15,75 \%) \text {, three participants } \\
\text { were African-American (15\%), one was } \\
\text { Asian-American (5\%), and one was } \\
\text { multiracial }(5 \%) \\
\text { SO not stated }\end{array}$ & Acute forensic \\
\hline $\begin{array}{l}\text { Courey et al. } 2008 \\
{[27]}\end{array}$ & $\begin{array}{l}\text { Qualitative, } \\
\text { structured } \\
\text { interview with } \\
\text { some open } \\
\text { questions }\end{array}$ & USA & $\begin{array}{l}\text { To use Hildegard Peplau's (1952) } \\
\text { conceptualization of nurses' helping roles (i.e. } \\
\text { stranger, resource person, teacher, } \\
\text { leadership, surrogate, counselor, technical } \\
\text { expert) in nurse-client interactions to explore } \\
\text { how survivors of sexual violence perceive } \\
\text { their encounters with health care } \\
\text { professionals. }\end{array}$ & $\begin{array}{l}\mathrm{N}=60 ; \\
\text { Female } \mathrm{n}=30 \text {, Male } \mathrm{n}=30 \\
\text { All White } \\
\text { SO not stated }\end{array}$ & $\begin{array}{l}\text { Community-based } \\
\text { recruitment }\end{array}$ \\
\hline
\end{tabular}




\begin{tabular}{|c|c|c|c|c|c|}
\hline $\begin{array}{l}\text { Denov et al. } 2003 \\
\text { [5] }\end{array}$ & Qualitative, & Canada & $\begin{array}{l}\text { To explore the experiences of victims of } \\
\text { female sex offenders with regard to disclosing } \\
\text { sexual abuse to a professional, and } \\
\text { importantly, the impact of professional } \\
\text { responses on victims }\end{array}$ & $\begin{array}{l}N=14 ; \\
\text { Female } n=7 \text {, Male } n=7 \\
\text { White } n=13 ; \\
\text { SO not stated }\end{array}$ & Not stated \\
\hline $\begin{array}{l}\text { Du Mont et al. } \\
2009[28]\end{array}$ & $\begin{array}{l}\text { Qualitative, } \\
\text { semi-structured } \\
\text { individual } \\
\text { interviews }\end{array}$ & Canada & $\begin{array}{l}\text { To gain an in-depth understanding of } \\
\text { women's experiences of attending medical } \\
\text { forensic examination for sexual violence }\end{array}$ & $\begin{array}{l}\mathrm{N}=19 ; \\
\text { Female; } \\
\text { White } \mathrm{n}=11, \mathrm{BME} \mathrm{n}=8 \\
\text { SO not stated }\end{array}$ & $\begin{array}{l}\text { Sexual Assault and } \\
\text { Domestic Violence } \\
\text { Treatment Centres }\end{array}$ \\
\hline $\begin{array}{l}\text { Draucker et al. } \\
1997[29]\end{array}$ & $\begin{array}{l}\text { Qualitative, } \\
\text { unstructured } \\
\text { interviews and } \\
\text { group } \\
\text { discussions }\end{array}$ & USA & $\begin{array}{l}\text { To describe male survivors' perceptions of } \\
\text { their therapeutic needs and therapy } \\
\text { experiences }\end{array}$ & $\begin{array}{l}\mathrm{N}=19 \text { (interviews } \mathrm{n}=12 \text {, group discussion } \\
\mathrm{n}=7 \text { ); } \\
\text { Male; } \\
\text { White } \mathrm{n}=17 \text {, Hispanic } \mathrm{n}=2 ; \\
\text { SO not stated }\end{array}$ & Mental health \\
\hline $\begin{array}{l}\text { Ericksen et al. } \\
2002[30]\end{array}$ & $\begin{array}{l}\text { Qualitative, } \\
\text { semi-structured } \\
\text { individual } \\
\text { interviews }\end{array}$ & USA & $\begin{array}{l}\text { To (1) understand the experience of women } \\
\text { who were sexually assaulted and then cared } \\
\text { for in an emergency setting by professionals } \\
\text { associated with a specialized sexual assault } \\
\text { service; (2) discover themes in the } \\
\text { experiences of these women; and (3) discern } \\
\text { implications of this experience for delivery of } \\
\text { care to women who have been sexually } \\
\text { assaulted. }\end{array}$ & $\begin{array}{l}\mathrm{N}=8 ; \\
\text { Female; } \\
\text { Ethnicity not stated; } \\
\text { SO not stated }\end{array}$ & $\begin{array}{l}\text { Emergency } \\
\text { department of a } \\
\text { large metropolitan } \\
\text { hospital }\end{array}$ \\
\hline $\begin{array}{l}\text { Fehler-Cabral et } \\
\text { al. } 2011[31]\end{array}$ & $\begin{array}{l}\text { Qualitative, } \\
\text { semi-structured } \\
\text { individual } \\
\text { interviews }\end{array}$ & USA & $\begin{array}{l}\text { To explore rape survivors' experiences with } \\
\text { forensic nurse examiners, to understand how } \\
\text { forensic nurses play a role in emotional } \\
\text { wellbeing and recovery }\end{array}$ & $\begin{array}{l}\mathrm{N}=20 \\
\text { Female } \\
\text { White } 85 \% \\
\text { SO not stated }\end{array}$ & $\begin{array}{l}\text { Community-based } \\
\text { recruitment }\end{array}$ \\
\hline $\begin{array}{l}\text { Koehn et al. } 2007 \\
\text { [32] }\end{array}$ & $\begin{array}{l}\text { Qualitative, } \\
\text { semi-structured } \\
\text { individual } \\
\text { interviews }\end{array}$ & Canada & $\begin{array}{l}\text { To explore women's perceptions of power } \\
\text { and control in sexual abuse counselling }\end{array}$ & $\begin{array}{l}N=50 ; \\
\text { Female; } \\
\text { White } n=43 \text {, Aboriginal } n=5 \text {, Asian } n=1 \text {, } \\
\text { South Asian } n=1 ; \\
\text { SO not stated }\end{array}$ & $\begin{array}{l}\text { Community } \\
\text { recruitment }\end{array}$ \\
\hline $\begin{array}{l}\text { Sigurdardottir et } \\
\text { al. } 2016 \text { [33] }\end{array}$ & $\begin{array}{l}\text { Qualitative, in- } \\
\text { depth } \\
\text { phenomenologi } \\
\text { cal individual } \\
\text { interviews }\end{array}$ & Iceland & $\begin{array}{l}\text { To present a description of a Wellness- } \\
\text { Program, evaluation of the different therapies } \\
\text { in the program, as well as a qualitative study } \\
\text { on their experience of the program's effects } \\
\text { on their life, health and well-being. }\end{array}$ & $\begin{array}{l}\mathrm{N}=10 ; \\
\text { Female; } \\
\text { Ethnicity not stated; } \\
\text { SO not stated }\end{array}$ & $\begin{array}{l}\text { Wellness Program } \\
\text { based in healthcare } \\
\text { system }\end{array}$ \\
\hline
\end{tabular}


We first provide a summary of the quantitative study findings, then the qualitative findings before bringing these together in our discussion section.

\section{Quantitative Studies}

The 10 quantitative and mixed method studies used cross-sectional surveys but no PROM or PREM regarding health care after sexual violence was identified. The cross-sectional surveys collected patient data on the type and experience of health care offered. Study quality is summarised in Table S1 and no study was excluded on the basis of quality. A validation process for survey development was reported in 3 of 10 studies, $[16,18,26]$ but none used a comprehensive approach to questionnaire design, incorporating patient input, and assessment of validity, acceptability, feasibility and reliability.

The survey questionnaires were delivered using a verbal format in a face-to-face interview setting $(\mathrm{n}=4)$, by phone $(n=2)$, and by self-administered written questionnaire $(n=6)$. Some studies used more than one method of data collection. Seven studies were based in USA, two in UK and one in France. Four were delivered in acute medical settings (including forensic suites), three in mental health settings and three in community support settings (e.g. Rape Crisis). Convenience sampling was used in most instances. Regarding study participants, six studies had exclusively women participants with the remaining four studies having only $5 \%$ male participants (35/700). Only one study recorded information on sexuality: among the all-women sample, $69.5 \%$ identified as heterosexual, and $31.5 \%$ homosexual, bisexual or unsure. There was a paucity of data on ethnicity with five studies not reporting on this and the remainder including predominantly Caucasian participants. Study sample size ranged from 52-365 respondents.[26, 34]

Some surveys were supplemented by validated assessment tools, such as the Counselling Outcome Index (COI), Posttraumatic Stress Index (PSI), Posttraumatic Stress Diagnostic Scale (PDS), Beck Depressive inventories, Michigan Alcoholism Screening Test (MAST), Rape Attribution Questionnaire (RAQ), Brief COPE, CSED-10 (Centre of Epidemiologic Studies Depression Scale, short version), used to measure specific outcomes relating to the service provided. Starzynski (2011) used a range of validated tools in an attempt to understand factors behind whether support from mental health care professionals was found to be helpful by women who attended their services.[26] The Social Reactions Questionnaire (SRQ) tool was used to assess positive reactions (emotional support and tangible aid support) and negative reactions (e.g. treated differently, control removed, victim blame); [35] and another, Frazier's tool, was used to assess women's perceptions of control over the recovery process from their sexual assault experience.[36]

The predominant themes incorporated into questionnaires covered two main areas; services offered or received, and interaction with healthcare professionals, with findings summarised in Table 2. Services 
included direct medical care (for example trauma care, sexual health, gynaecology), forensic medical examination (which may or may not have involved police and legal services), psychological health care, and the provision of healthcare information. A wide variation was found in the availability and delivery of key services including testing for sexually transmitted infections, offering prophylactic antibiotics and provision of HIV secondary prophylaxis following assault, but the relative importance of these services were to survivors of sexual violence was not clear. Forensic examination to support a criminal investigation was performed in a variable proportion of patients which appeared to depend partly on the setting at presentation, but a number of studies noted that such an examination had either not been expected or was not wanted. There was a strong focus on physical care and the limited provision of mental health support was evident despite this being identified by patients as being of importance to them and helpful when available.

Where studies addressed the interaction with healthcare professionals in addition to health services, some participants raised concerns on not feeling empowered, safe, being believed or receiving compassionate care. $[16,17,24,26]$ The majority of patients reported that the planned clinical procedures were explained to them in advance, but a significant minority felt that this was not the case and that they did not have full control over what was happening nor that a full explanation had been provided. The sense of being in control during the consultation was linked by patients to greater engagement with care, improved mental health and a higher chance of attending future healthcare appointments. A good personal interaction between the individual healthcare worker and patient, in contrast to a more clinical or impersonal approach, was also identified as being important to patients as was the perception that staff had a non-judgemental attitude.

The provision of information to patients varied widely but was particularly low for HIV advice and information regarding mental health support.

\section{Qualitative studies}

No qualitative study was excluded on the basis of quality but two common limitations of the qualitative studies were: the lack of a statement locating the researcher culturally or theoretically, and; any acknowledgement or explanation as to the researchers influence upon the research, or vice versa (Table S2).

Of the 10 qualitative studies, five were conducted in the USA, three in Canada, and one each in Brazil, and Iceland. Most studies employed semi-structured, individual interviews, with participant numbers ranging from 8 [30] to 60. [27] Two studies included men as well as women, [5, 27] one men only, [29] and seven with recruited women only. Although the age-range varied, most included participants between the ages of 20 and 50 years, with one study focusing exclusively on adolescents. [37] Table $1 \mathrm{~b}$ shows characteristics of study participants, including limited data on sexual orientation. Although the 
main areas identified as being of importance varied, there were two discernible overarching themes: firstly, the importance of communication prioritising the patient and encompassing trauma-informed care; secondly, patients prioritised care that enhanced their power and control.

\section{Patient- and trauma-focused communication}

Every identified qualitative study conveyed a key theme related to the importance of patient-focused communication that was trauma-informed (i.e., avoidance of re-traumatisation and being attentive to signs and symptoms of trauma), [38] as an important component of the patient experience. Such communications were important to patients from initial contact with the service, including reception areas, and subsequently in consultation with the healthcare professional. Barros et al. (2015) provided a woman's account of how it felt to have no privacy within the reception area of a maternity service:

My husband had to speak near another person, she heard it all. (...) She turned her face to look at me. If there was a hole I could've hidden in, I would have stuck my head there and never gotten out of it. (...) [3: 196]

Initial responses by whomever deals with a patient are important so as not to re-traumatise the patient who has overcome many hurdles to access care. A key aspect of this is for healthcare professionals to clearly convey belief in the patients' experience.[5, 27, 31,37] Both Campbell et al. (2013) and Denov et al. (2003) found some participants experienced disbelief from healthcare professionals when first revealing their sexual abuse. $[5,37]$ Disbelief was particularly prominent for those who disclosed their abuse was perpetrated by a woman:

I left her office startled, confused, hurt and very angry to have a person who is supposed to be a healing professional, who cannot afford to be naive, express shock that a woman is capable of sexual abuse ...I found that attitude repeated again and again" (Female \#1).[5: 55]

As patients progressed from the first response and moved through their healthcare experience, they prioritised the building of trust and compassionate care, and how processes and procedures were communicated throughout contributed to care being experienced as such. Four studies noted the importance of gaining trust throughout care, whether to perform an intimate physical examination or throughout the therapy process.[27, 32, 33, 37]

She just slowly got into it. And she got my confidence and trust and stuff.[37: 72]

Four studies identified compassionate care from healthcare staff as being important in achieving a positive experience. $[27,28,30,31]$ Three studies [27, 28, 31] conveyed patient experiences of 
compassionate care linked to non-judgemental attitudes, whereas participants in the Erkisen et al (2002) study spoke more broadly about compassion stemming from being treated as a whole person rather than focusing on clinical aspects of care:

"They were just very human...not clinical about it...and it was that shared humanity that meant the most to me.’[30: 87]

Two studies noted the importance patients attributed to being given clear information throughout their care, regardless of whether this was a forensic examination or counselling.[3, 31]

\section{Empowerment}

The theme of patients receiving care that enabled them to experience control emerged across all ten qualitative studies. [3, 5, 27-33, 37] A key starting point for enabling patients' empowerment is to unequivocally believe patients and for their abuse experience to be taken seriously.[5, 27, 31, 37] Conversely, patients noted their negative experiences with healthcare after sexual violence, including struggling with recovery, stemmed from not being believed, or indeed the abuse being minimised.[5, 27] For many patients, an important aspect of care they valued in addition to being given clear information was to then be offered choice. Thus, good care from the patient perspective was less about having tests or a procedure, than being offered the choice for them.

She [nurse examiner] just like making sure that I knew what she was doing and I was like comfortable with it. Making sure that I knew that if it wasn't something that I was comfortable with I didn't have to do it.[37]

As Campbell et al. (2013) state, 'Empowering patients to decide the scope of their care' is important.[37: 72] Courey et al. (2008) describe this as "working with them "as a team" or providing direction without taking charge,' [27] and in another study this was described as patients 'setting the pace for the examination'. [30] Healthcare provision that enables patients to feel empowered was important to patients across all settings, whether in a clinical setting for a forensic examination or in a counselling service. For example, in relation to counselling, one participant said

People should have to ask your permission before they march into the centre of your soul.[32:49]

Six studies associated the experience of care received with specific physical and cognitive-affect-related outcomes, including: 'healing',[5, 27, 31] overall wellbeing,[5, 31] increased agency, self-efficacy and self-esteem,[32,33] gaining control and confidence to enable recovery,[31] positive impact on relationships, including intimate relationships,[33] and positive impact on physical health.[33] 
Conversely, feeling disempowered from poor care could negatively impact on care continuation and ultimately health and wellbeing outcomes.[5, 32]

\section{DISCUSSION}

This systematic review sought to understand patient reported experiences and outcomes after attending health services for care after sexual violence. The review found no 'gold standard' measure of PROMs or PREMs, leaving challenges for service providers wanting to evaluate and improve the health care offered. Disclosure of sexual violence allows patients to start accessing appropriate health care, whether to receive a forensic examination, sexually transmitted infection testing or counselling. The included qualitative studies provide useful insights into patient experiences and point strongly to the importance of good communications that allowed a patient to perceive their care as creating trust and conveying compassion. Studies also emphasised the importance of patients feeling empowered throughout their care experience, from the initial encounter and with subsequent interactions with staff. Two issues arise from these findings: first, a methodological issue regarding the need to develop a theoretical framework and identification of key domains of empowerment and effective communication if such a concepts are to take prominence in a measure of quality of care;[39] second, clear management pathways and staff training are likely to be required to meet these patient defined goals.

The quantitative studies used validated tools to assess specific care-related outcomes but did not have patient reported experience or outcome measures. They did, however, provide evidence of the types of acute health care response offered after sexual violence, including: emergency contraception, HIV prophylaxis, protective vaccinations and infection testing (Table 2). Although such procedures may be a relevant component of medical care, from a patient perspective it was equally or more important that care was personalised and that choices were provided before agreeing whether to proceed or not. Additionally, such outcomes and experiences related to acute healthcare cannot necessarily be assumed to be what patients consider to be the most important measures of quality. However, the items listed in the surveys were based on expert opinion and reflect national guidelines, such as BASHH Management of Adult and Adolescent Complainants of Sexual Assault.[40]

The evidence base was limited, particularly when compared with the intervention literature and there are missing voices, either through lack of research focus or from lack of reporting. In particular, it is striking that only one study noted the sexual orientation of the study population.[26] If LGBT identifying individuals are making use of healthcare services they need to be asked about their experiences and outcomes so that we can reflect on similarities and differences with a heterosexual population. A similar omission occurred for men with the majority of studies focused on women only.[29] There have been no studies published in the past 20 years on men's experiences of healthcare after sexual violence. These are two important gaps in the evidence, which should be addressed with further research. 
Our review should be read with various limitations in mind, including our use of a broad definition of 'healthcare setting' incorporating a wide variety of venues which may limit the applicability of our findings in specific settings. This did, however, increase the likelihood of identifying relevant PROMs or PREMs. Our decision to include all study designs allowed us to capture a wide range of evidence to ensure a greater understanding of what matters to patients in this situation. It is also possible that despite using broad parameters, multiple databases and grey sources, we could still have missed relevant studies.

\section{CONCLUSION}

This systematic review reveals a number of important points for future practice and research. A key practice point is that sympathetic and clear communication is of central importance. Healthcare staff should be trained to offer healthcare choices after sexual violence, but to accept (and to show an understanding) when these are declined. Patients want care that empowers them and gives them back control, and such empowerment should be considered an outcome as well as an experience. Whilst the value of patient autonomy is well recognised, in this patient group there needs to be a greater recognition that it plays a significant part of the recovery process. The central theme of empowerment and control also needs to have greater prominence in guidelines. Future research to develop a measure of quality of care after sexual violence needs to include patient input, and a focus on operationalising the concepts of empowerment and effective communication within an outcome measure.

\section{Key Messages}

- No patient reported outcome or experiences measures are currently available for assessing healthcare after sexual violence

- The importance of trauma-informed care (i.e., avoidance of re-traumatisation and being attentive to signs and symptoms of trauma) and a health care interaction that supports patients' own power and control during recovery were regarded as priorities by patients

- The central theme of patient empowerment and control should have greater prominence in both practice and guidelines

- Significant gaps in the evidence base were noted, particularly the missing voices of men and the LGBT community

Contributors RC and JR had the initial idea and concept. RC developed the idea and wrote the protocol. $\mathrm{RC}$ undertook the literature searches. RC and KL reviewed the titles, abstracts and full-text papers, and extracted the data. All authors contributed to the writing of the manuscript and approved the final version.

\section{Acknowledgements}


Dr Joseph Heskin (Beaumont Hospital, Dublin) assisted with data management of the review searches.

\section{Competing Interests}

JR has received fees from GSK, Hologic Diagnostics, Janssen, and Mycovia Ltd outside the submitted work; and has shares in GSK Pharma and Astrazeneca Pharma. He is a member of the European Sexually Transmitted Infections Guidelines Editorial Board.

\section{Role of the funding source}

This study was jointly funded by a grant from the Sexually Transmitted Infection Research Foundation (Registered Charity Number 1075316) and the Queen Elizabeth Hospital Charity (Registered Charity Number 1165716). The funders of the study had no role in study design, data collection, data analysis, data interpretation or writing of the report.

The Corresponding Author has the right to grant on behalf of all authors and does grant on behalf of all authors, an exclusive licence (or non exclusive for government employees) on a worldwide basis to the BMJ Publishing Group Ltd to permit this article (if accepted) to be published in STI and any other BMJPGL products and sub-licences such use and exploit all subsidiary rights, as set out in our licence http://group.bmj.com/products/journals/instructions-for-authors/licence-forms 
1. Jewkes R, Sen P, Garcia-Moreno C. Sexual Violence In: Etienne G. Krug, Linda L. Dahlberg, James A. Mercy, Anthony B. Zwi, Rafael Lozano, eds. World report on violence and health. Geneva, Switzerland: World Health Organization 2002:147-81.

2. NHS England. Strategic direction for sexual assault and abuse services - Lifelong care for victims and survivors: 2018 - 20232018.

3. Barros LdA, Albuquerque MCDSd, Gomes NP, Riscado JLdS, Araújo BROd, Magalhães JRFd. The (un)receptive experiences of female rape victims who seek healthcare services. Revista da Escola de Enfermagem da U S P 2015;49:193-200 doi: 10.1590/S0080-623420150000200002

4. Campbell R, Greeson MR, Fehler-Cabral G. With care and compassion: Adolescent sexual assault victims' experiences in sexual assault nurse examiner programs. J Forensic Nurs 2013;9:68-75 doi: 10.1097/JFN.0b013e31828badfa.

5. Denov MS. To a safer place? Victims of sexual abuse by females and their disclosures to professionals. Child Abuse \& Neglect 2003;27:47-61 doi: 10.1016/S0145-2134(02)00509-4.

6. NHS England. Creating the conditions for person-centred care. https://www.england.nhs.uk/ourwork/patient-participation/patient-centred/.

7. NICE. Patient experience in adult NHS services: improving the experience of care for people using adult NHS services. https://www.nice.org. uk/guidance/cg138 2012.

8. Patterson D, Greeson M, R. C. Understanding rape survivors' decisions not to seek help from formal social systems. Health Soc Work 2009;34:127-36 doi: 10.1093/hsw/34.2.127.

9. Fujisawa R, Klazinga N. Measuring patient experiences (PREMS): Progress made by the OECD and its member countries between 2006 and 2016, OECD Health Working Papers, No. 102. Paris, http://dx.doi.org/10.1787/893a07d2-en: OECD Publishing, 2017.

10. Weston RL, Hopwood B, Harding J, Sizmur S, Ross JDC. Development of a validated patient satisfaction survey for sexual health clinic attendees. Int J STD AIDS 2010;21:584-90 doi: 10.1258/ijsa.2010.010159.

11. Caswell R, Lorimer K, Ross J. Assessing the measurement of patient experience and outcome in health care settings on receiving care after sexual violence: a protocol for a systematic review. 2016. http://www.crd.york.ac.uk/PROSPERO/display_record.php?ID=CRD42016050297.

12. The Joanna Briggs Institute. Joanna Briggs Institute Reviewers' Manual: 2016 edition. Australia: The Joanna Briggs Institute, 2016.

13. Prinsen C, Mokkink L, Bouter L, et al. COSMIN guideline for systematic reviews of patient-reported outcome measures. Qual Life Res 2018;27:1147-57.

14. The Joanna Briggs Institute. Checklist for Qualitative Research. http://joannabriggs.org/research/critical-appraisal-tools.html.

15. Ritchie J, Lewis J. Qualitative research practice: A guide for social science students and researchers: Sage Publications Ltd, 2003.

16. Campbell R. What Really Happened? A Validation Study of Rape Survivors' Help-Seeking Experiences With the Legal and Medical Systems. Violence and Victims 2005;20:55-68.

17. Campbell R. Rape Survivors' Experiences With the Legal and Medical Systems: Do Rape Victim Advocates Make a Difference? Violence Against Women 2006;12:30-45 doi: $10.1177 / 1077801205277539$.

18. Campbell R, Patterson D, Adams AE, Diegel R, Coats S. A participatory evaluation project to measure SANE nursing practice and adult sexual assault patients' psychological well-being. $J$ Forensic Nurs 2008;4:19-28 doi: 10.1111/j.1939-3938.2008.00003.x.

19. Denis C, Seyller M, Chariot P. Expectations and perceptions of care among victims of sexual assault who first seek care from emergency, primary care and gynaecological doctors. Emerg Med $J$ 2015;33:134-8 doi: 10.1136/emermed-2015-204655.

20. Hall Z, King E. Group therapy within the NHS V: Patients' views on the benefit of group therapy for women survivors of child sexual abuse. Group Analysis 1997;30:409-27 doi: $10.1177 / 0533316497303009$ 
21. Monroe LM, Kinney LM, Weist MD, Dafeamekpor DS, Dantzler J, Reynolds MW. The Experience of Sexual Assault: Findings From a Statewide Victim Needs Assessment. J Interpers Violence 2005;20:767-76 doi: 10.1177/0886260505277100.

22. Smith D, Pearce L, Pringle M, Caplan R. Adults with a history of child sexual abuse: Evaluation of a pilot therapy service. $B M J 1995 ; \mathbf{3 1 0}: 1175-78$.

23. Wasco SM, Campbell R, Howard A, et al. A statewide evaluation of services provided to rape survivors. J Interpers Violence 2004;19:252-63 doi: 10.1177/0886260503260246.

24. Zweig JM, Burt MR. Predicting women's perceptions of domestic violence and sexual assault agency helpfulness: What matters to program clients? Violence Against Women 2007;13:1149-78 doi: $10.1177 / 1077801207307799$.

25. Lewis-O'Connor A, Chadwick M. Engaging the Voice of Patients Affected by Gender-Based Violence: Informing Practice and Policy. Journal of forensic nursing 2015;11:240-49 doi: 10.1097/JFN.0000000000000090

26. Starzynski L. Women's experiences disclosing sexual assault to mental health professionals: A multimethod approach. Dissertation Abstracts International Section A: Humanities and Social Sciences 2011;71.

27. Courey TJ, Martsolf DS, Draucker CB, Strickland KB. Hildegard Peplau's theory and the health care encounters of survivors of sexual violence. J Am Psychiatr Nurses Assoc 2008;14:136-43 doi: 10.1177/1078390308315613

28. Du Mont J, White D, McGregor MJ. Investigating the medical forensic examination from the perspectives of sexually assaulted women. Soc Sci Med 2009;68:774-80 doi: 10.1016/j.socscimed.2008.11.010.

29. Draucker CB, Petrovic K. Therapy with male survivors of sexual abuse: The client perspective. Issues in Mental Health Nursing 1997;18:139-55 doi: 10.3109/01612849709010330

30. Ericksen J, Dudley C, McIntosh G, Ritch L, Shumay S, Simpson M. Clients' experiences with a specialized sexual assault service. J Emerg Nurs 2002;28:86-90 doi: 10.1067/men.2002.121740

31. Fehler-Cabral G, Campbell R, Patterson D. Adult sexual assault survivors' experiences with sexual assault nurse examiners (SANEs). Journal of Interpersonal Violence 2011;26:3618-39.

32. Koehn CV. Women's Perceptions of Power and Control in Sexual Abuse Counseling. J Child Sex Abuse; 2007;16:37-60 doi: 10.1300/J070v16n01_03

33. Sigurdardottir S, Halldorsdottir S, Bender SS, Agnarsdottir G. Personal resurrection: female childhood sexual abuse survivors' experience of the Wellness-Program. Scand J Caring Sci 2016;30:175-86 doi: 10.1111/scs.12238.

34. Campbell R, Patterson D, Adams AE, Diegel R, Coats S. A participatory evaluation project to measure SANE nursing practice and adult sexual assault patients' psychological well-being. $J$ Forensic Nurs 2008;4:19-28 doi: 10.1111/j.1939-3938.2008.00003.x.

35. Ullman SE. Psychometric characteristics of the Social Reactions Questionnaire: A measure of reactions to sexual assault victims. Psychology of Women Quarterly 2000;24:169-83 doi: 10.1111/j.1471-6402.2000.tb00208.x.

36. Frazier PA. Perceived control and distress following sexual assault: A longitudinal test of a new model. J Pers Soc Psychol 2003;84:1257-69 doi: 10.1037/0022-3514.84.6.1257.

37. Campbell R, Greeson MR, Fehler-Cabral G. With care and compassion: Adolescent sexual assault victims' experiences in sexual assault nurse examiner programs. $J$ Forensic Nurs 2013;9:68-75 doi: 10.1097/JFN.0b013e31828badfa.

38. Elliott DE, Bjelajac P, Fallot RD, Markoff LS, Glover Reed B. Trauma-informed or trauma denied: Principles and implementation of trauma-informed services for women. J Community Psychol 2005;33:461-77 doi: 10.1002/jcop.20063.

39. McAllister M, Dunn G, Payne K, Davies L, Todd C. Patient empowerment: The need to consider it as a measurable patient-reported outcome for chronic conditions. BMC Health Serv Res 2012;12:157 doi: 10.1186/1472-6963-12-157.

40. BASHH. UK National Guidelines on the Management of Adult and Adolescent Complainants of Sexual Assault: https://www.bashhguidelines.org/media/1079/4450.pdf, 2011. 